Dhaka Univ. J. Biol. Sci. 26(1): 1-11, 2017 (January)

\title{
BACTERIAL AND CHEMICAL POLLUTION LEVEL OF THE RIVER TURAG, GAZIPUR, BANGLADESH
}

\author{
Mihir Lal SAHA*, MD. AtiQ Mahbub, Tahsin Khan, \\ M. MONIRUZZAMAN ${ }^{1}$ AND Sirajul HoQUE ${ }^{2}$ \\ Department of Botany, University of Dhaka, Dhaka-1000, Bangladesh
}

Key words: Turag River, Bacteria, Enteric bacteria, Water pollution, Chemical pollution

\begin{abstract}
The river Turag is the upper tributary of the river Buriganga in Bangladesh. Aerobic heterotrophic bacterial count of the river in nutrient agar (NA) and peptone yeast extract glucose (PYG) agar media ranged from $2.91 \times 10^{5}$ to $27.5 \times$ $10^{5} \mathrm{cfu} / \mathrm{ml}$ and from $1.09 \times 10^{5}$ to $19.3 \times 10^{5} \mathrm{cfu} / \mathrm{ml}$, respectively. Enteric and related bacterial count on MacConkey agar was between $0.88 \times 10^{3}$ and $20.8 \times 10^{3}$ $\mathrm{cfu} / \mathrm{ml}$. Out of 91 isolated bacterial isolates, 30 were selected based on their distinctive colony morphology for detailed study. Among these, 16 were Grampositive (53\%) and 14 were Gram-negative (47\%). Bacillus was dominant among the Gram-positive isolates (69\%). The remaining were Brochothrix thermosphacta (6\%), Caryophanon sp. (19\%) and Renibacterium salmoninarum (6\%). Fourteen Gram-negative, enteric and related isolates were identified as Plesiomonas shigelloides (43\%), Alcaligenes denitrificans (22\%), E. coli $(14 \%)$, Proteus $(14 \%)$ and Citrobacter freundii (7\%). Biological oxygen demand (BOD) and chemical oxygen demand (COD) values were about 9 and 5-fold higher than standard values whereas dissolved oxygen (DO) of the river was found to be six times less than the standard value. The maximum average TDS, conductivity and turbidity was recorded during the summer season as $441.75 \pm 15.52 \mathrm{mg} \Lambda, 858.25 \pm 19.57 \mu \mathrm{S} / \mathrm{cm}$ and $79.53 \pm 6.49 \mathrm{NTU}$, respectively. Chemical contents viz. sulphate, chloride and fluoride were found to be satisfactory from pollution point of view. Both BOD and COD values along with the abundance of different heterotrophic and enteric bacteria clearly indicated that the river Turag was polluted with organic, chemical and bacterial pollutants.
\end{abstract}

\section{Introduction}

Dhaka, the capital and most populated city in Bangladesh is now a member of mega city family in the world. Rapid and unplanned urbanization, commercial development along with population pressure have made it an environmentally polluted city in the world ${ }^{(1-2)}$. In Bangladesh, about $80 \%$ of all diseases are associated with waterborne

*Author for correspondence: <sahaml@yahoo.com>. 1 Soil and Environment Section, Biological Research Division, BCSIR Laboratories, Dhaka. ${ }^{2}$ Department of Soil, Water and Environment, University of Dhaka, Dhaka-1000, Bangladesh. 
pathogen. About 300,000 children under five die of diarrhoeal diseases every year, of which one third of the deaths occurs in the city slums and squatter settlements(3). Pathogenic bacteria that have been transmitted by water or waste water include Salmonella, Campylobacter, Vibrio cholarae, Leptospira and Yersinia.

Dhaka metropolis is bounded from northwest side by the river Turag, northeast side by Baloo and Sitalakkhya and extreme south side by Buriganga. The catchment of the river Turag is occupied by nearly one third of the total population of Dhaka. There are many industries dotting the banks of this river which dispose their industrial waste into the river that pollute the water of the river to a dangerous level. Concentrations of $\mathrm{Cd}, \mathrm{Pb}$ and $\mathrm{Cr}$ were found higher in different stations in the course of Buriganga, Sitalakhya and Turag rivers(4). In the recent past, sporadic information on some physicochemical variables including the concentration of some heavy metals on the river Turag has been published(5-6). Studies on the pollution aspects of this kind of water are very significant because these settlements use this water for various domestic purposes ${ }^{(7)}$.

Therefore, the present study was undertaken to determine the aerobic heterotrophic and enteric bacteria in the context of biological pollution level along with the physicochemical properties of the river Turag to reveal an overall status of pollution of the river Turag.

\section{Materials and Methods}

Sampling sites and collection of water samples: The water samples were collected from four selected sites (T-1 to T-4) of the river Turag, Dhaka, Bangladesh (Fig. 1) in three different seasons considering possible sources of pollution. Water samples were collected in plastic bottles sterilized with alcohol.

Bacteriological analysis: Nutrient agar (NA) and peptone yeast extract glucose (PYG) medium were used for the enumeration and isolation of aerobic heterotrophic bacteria present in samples while MacConkey agar (Oxoid) medium was used enteric bacteria. The $\mathrm{pH}$ of the media was adjusted to 7.2 before sterilization. Two different techniques viz. serial dilution plate ${ }^{(8)}$ and membrane filtration were used for the enumeration and isolation of bacteria. The inoculated plates were inverted and incubated at $37^{\circ} \mathrm{C}$ for $24 \mathrm{hrs}$ in an incubator (Memmert $\mathrm{GmbH}+\mathrm{Co} \mathrm{Kg} 8540$ Sehwabach). After 24 hrs of incubation the plates with well discrete colonies were selected for counting. Using colony counter (Digital colony counter, DC-8 OSK 100086, Kayagaki, Japan) the developed colonies were counted.

Discrete bacterial colonies were isolated immediately after counting. Further selection of the isolates was made on the basis of their different colony morphology. For provisional identification of bacteria, important biochemical tests were carried out viz. carbohydrate fermentation, catalase test, deep glucose agar test, tyrosine degradation, egg-yolk lecithinase test, casein hydrolysis, gelatin hydrolysis, starch hydrolysis, Kligler's 
iron agar (KIA) test, levan test, methyl red test, nitrate reduction test, oxidase test, indole production test, utilization of citrate and propionate, urease production test, VogesProskauer (VP) test etc. ${ }^{(9-12)}$. Bergey's Manual of Systematic Bacteriology (Vol. 2)(12) was followed for the identification of Gram-positive aerobic heterotrophic bacterial isolates. On the other hand, enteric bacteria were identified by using standard method following Manual for Laboratory Investigations of Acute Enteric Infections ${ }^{(13)}$ and Bergey's Manual of Systematic Bacteriology (Vol. 1)(14).

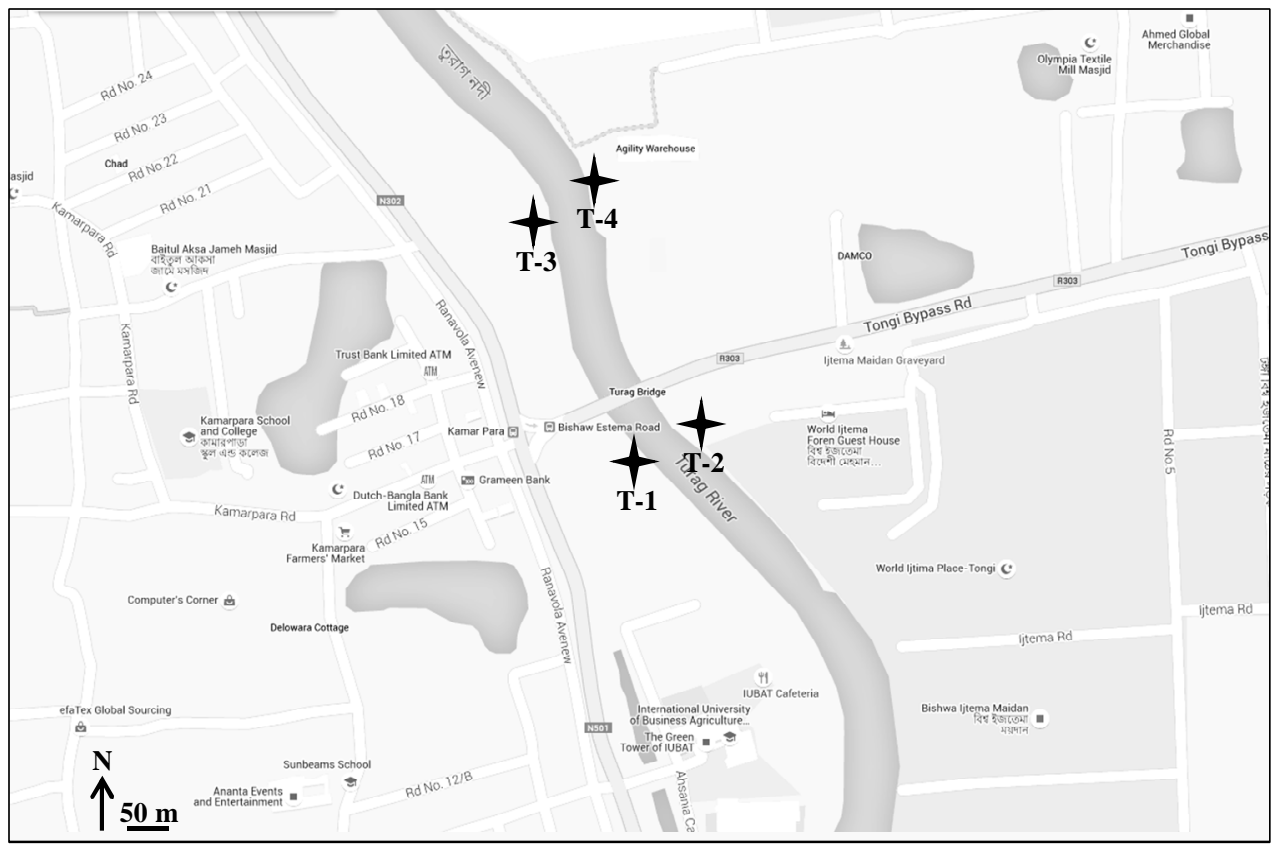

Fig. 1. Map showing different sampling sites from the river Turag. T-1: Kamarpara bridge, T-2: Ijtema field, T-3: Rusadia Gudar quay and T-4: Mill gate.

Determination of physicochemical properties: The $\mathrm{pH}$ of collected water samples was measured in the laboratory by glass electrode using $\mathrm{pH}$ meter (HM-31P, DKK-TOA Corp., Japan)(15). Temperature of the sample water was measured at the time of water sampling with the help of a thermometer. For chemical analysis, samples were filtered (Whatman No. 42, England) to eliminate suspended solid particles. Dissolved oxygen of water was determined by DO meter (HACH HQ 30d). Biochemical Oxygen Demand $\left(\mathrm{BOD}_{5}\right)$ of water samples was determined by Respirometric Method (APHA 5210D) using BOD Sensor Set (HACH BOD TRACK II). Chemical Oxygen Demand (COD) of water samples was determined by closed reflux, titrimetric method (APHA 5220C) using certified HACH COD vials and COD Reactor (ECO 8, VELP, Italy). Total Dissolved Solids (TDS) and conductivity of the collected samples were determined using multi 
range conductivity meter (HACH Sension 156 Conductivity meter). Turbidity of the water samples was determined using Turbidity meter (MODEL- 2100 Q, HACH, USA) followed by APHA $2130 \mathrm{~B}{ }^{(8)}$. Sulphate content of water samples was determined by turbidimetric method ${ }^{(16)}$. Chloride and fluoride contents of the water samples were determined by Ion Chromatography method (Dionex ICS-1600 Thermo Scientific, USA).

Statistical analyses: The data were analyzed to determine the descriptive statistics viz. statistical mean and standard deviation (SD) with SPSS v.16.0 for windows (SPSS, SAS Institute Inc. Cary, USA).

\section{Results and Discussion}

Bacterial count of the water samples of the river Turag revealed substantial number of aerobic heterotrophic bacteria (Table 1). The highest count $\left(27.5 \times 10^{5} \mathrm{cfu} / \mathrm{ml}\right)$ was found in the site T-4 (Mill gate) station in the late autumn season on NA medium while the lowest count $\left(1.09 \times 10^{5} \mathrm{cfu} / \mathrm{ml}\right)$ was found in the site T-1 (Kamarpara bridge) in the rainy season on PYG medium. The bacterial counts among the replicates were found to be varied and the maximum mean aerobic heterotrophic bacterial count $(13.63 \pm 9.10 \times$ $10^{5}$ ) was observed in the late autumn season. Enteric and related bacterial count on MacConkey agar ranged between $0.88 \times 10^{3}$ and $20.8 \times 10^{3} \mathrm{cfu} / \mathrm{ml}$ (Table 1) and the highest count was found in the sample of site T-4 (Mill gate) in the summer season. The maximum mean enteric and related bacterial count $\left(17.33 \pm 3.06 \times 10^{3}\right)$ was also observed in the summer. The results demonstrated that the river Turag is considerably polluted with bacterial population. Garnier et al.(17-18) and Hasan et al.(19) reported more or less similar results showing the load of heterotrophic and nitrifying bacteria in the river and sewage lagoon. The US Department of Interior, Federal Water Pollution Control Administration in its 1968 report on water quality stated the tolerable limit for recreation purposes up to $10 \mathrm{cfu} / \mathrm{ml}$ of total and $2 \mathrm{cfu} / \mathrm{ml}$ of fecal coliforms. In a different study, Saha et al. ${ }^{(20)}$ observed the aerobic heterotrophic bacterial count of the river Buriganga ranged from $1.0 \times 10^{5}$ to $42.0 \times 10^{5} \mathrm{cfu} / \mathrm{ml}$ while enteric bacterial counts MacConkey agar ranged from $0.3 \times 10^{3}$ to $3.5 \times 10^{4} \mathrm{cfu} / \mathrm{ml}$.

During this investigation, of the initial 91 isolates, 30 were selected on the basis of their distinctive colony morphology and purified for detailed study. Table 2 shows important biochemical tests for identification of the bacteria isolated from the river Turag. Out of the 30 isolates, 16 were Gram-positive and remaining 14 were Gramnegative. Among the Gram-positive isolates, all were rod shaped and 11 isolates were spore former and members of the genus Bacillus (69\%) and the remaining 5 were identified as Brochothrix thermosphacta (6\%), Caryophanon sp. (19\%) and Renibacterium salmoninarum (6\%).Under Bacillus there were 6 distinct species viz. B. acidocaldarius, B. coagulans, B. globisporus, B. lentus, B. pumilus and B. stearothermophilus. The result clearly indicated that (Fig. 2) among the Gram-positive bacteria, spore former Bacillus 
was the dominant genus (69\%). All the 14 Gram-negative isolates were short rods and non-spore former. Out of them, 6 isolates (43\%) were identified as Plesiomonas shigelloides, 3 isolates (22\%) were Alcaligenes denitrificans, 2 isolates (14\%) were Escherichia coli, 2 isolates $(14 \%)$ belonged to the genus Proteus and 1 isolate $(7 \%)$ was identified as Citrobacter freundii. Plesiomonas was found to be dominant genus among the Gramnegative bacteria in the river Turag. The coliform group of bacteria in general and E. coli in particular, was found to be universal indicator of fecal contamination ${ }^{(21)}$. Saha et al. ${ }^{(20)}$ reported the presence of Bacillus, Planococcus, Enterobacter, Alcaligenes, Salmonella, E. coli and Plesiomonas in the river water of Buriganga, Dhaka.

Physicochemical properties of the water of the river Turag are given in Table 3. During the rainy season, river Turag merges with vast areas of floodplain on both of its banks whereas in dry season the river becomes narrow. The $\mathrm{pH}$ ranged from 6.90 to 7.56. The mean value in summer as recorded in the present investigation $(6.99 \pm 0.08)$ is more or less similar to that of Sikder et al.(6). Water temperature ranged from 22.0 to $31.0^{\circ} \mathrm{C}$ whereas similar data $\left(20.82-30.50^{\circ} \mathrm{C}\right)$ is observed by Khondker and Abed (22). Both $\mathrm{pH}$ and temperature of the river Turag remains favorable for bacterial growth all throughout the year.

Khondker and Abed ${ }^{(22)}$ reported DO concentration of the river Turag as $0.45-13.3 \mathrm{mg} /$ but in the present study it ranged in between 0.21 and $0.99 \mathrm{mg} \Lambda$. According to Bangladesh Gazette(23), standard values for DO should be $6 \mathrm{mg} /$. So, the average DO value of the river Turag is approximately six times less than the standard value. Due to presence of oxygen demanding pollutants like organic wastes, there may have been a rapid depletion of dissolved oxygen from water. According to United State Public Health (USPH) standard, 5 and $4 \mathrm{mg} /$ value of BOD and COD, respectively indicate the quality for domestic and drinking water. The normal range of BOD for good water quality is 5 - 6 $\mathrm{mg} \Lambda$ and COD is $6-10 \mathrm{mg} \Lambda^{(24)}$. In this investigation BOD and COD values of the water samples ranged in between 29 and $65 \mathrm{mg} \Lambda$ and 31 and $79 \mathrm{mg} \Lambda$, respectively. Maximum average BOD $(49.50 \pm 15.29 \mathrm{mg} /)$ was found in the summer and maximum average COD $(64.03 \pm 5.74 \mathrm{mg} /)$ was found in the late autumn season. In comparison with the standard values, both BOD and COD of the river Turag were found to be 9 and 5 times higher than the standard. High BOD and COD values indicated that water of the river Turag was considerably polluted with organic and chemical pollutants.

The maximum average total dissolved solids (TDS), conductivity and turbidity of the river Turag were recorded during the summer season and these were $441.75 \pm 15.52 \mathrm{mg} \Lambda$, $858.25 \pm 19.57 \mu \mathrm{S} / \mathrm{cm}$ and $79.53 \pm 6.49 \mathrm{NTU}$, respectively. In a study, Khondker and Abed ${ }^{(22)}$ Turag with a clear peak concentration (around $900 \mu \mathrm{S} / \mathrm{cm}$ ) in April, which is somewhat similar to the data acquired in this piece of work (clear peak concentration 870 $\mu \mathrm{S} / \mathrm{cm}$ ). However, the mean conductivity of the river water is said to be increased by $7 \%$ in a recent study(6). According to Bangladesh Gazette(23), standard values for industrial 
Table 1. Bacterial count of water samples of the river Turag in different seasons and at different locations.

\begin{tabular}{|c|c|c|c|c|c|c|}
\hline \multirow[t]{2}{*}{ Seasons } & \multirow{2}{*}{$\begin{array}{l}\text { Sampling } \\
\text { site }\end{array}$} & \multicolumn{3}{|c|}{ Aerobic heterotrophic bacteria $(\mathrm{cfu} / \mathrm{ml})$ on } & \multicolumn{2}{|c|}{ Enteric and related bacteria $(\mathrm{cfu} / \mathrm{ml})$ on } \\
\hline & & NA & PYG & Average $\pm \mathrm{SD}$ & MacConkey agar & Average $\pm \mathrm{SD}$ \\
\hline \multirow{4}{*}{$\begin{array}{l}\text { Rainy } \\
\text { season }\end{array}$} & $\mathrm{T}-1$ & $3.30 \times 10^{5}$ & $1.09 \times 10^{5}$ & $4.19 \pm 3.89 \times 10^{5}$ & $2.01 \times 10^{3}$ & $2.56 \pm 1.79 \times 10^{3}$ \\
\hline & $\mathrm{T}-2$ & $13.1 \times 10^{5}$ & $2.82 \times 10^{5}$ & & $5.08 \times 10^{3}$ & \\
\hline & $\mathrm{T}-3$ & $4.14 \times 10^{5}$ & $1.37 \times 10^{5}$ & & $2.26 \times 10^{3}$ & \\
\hline & $\mathrm{T}-4$ & $5.57 \times 10^{5}$ & $2.14 \times 10^{5}$ & & $0.88 \times 10^{3}$ & \\
\hline \multirow{4}{*}{$\begin{array}{l}\text { Late } \\
\text { autumn }\end{array}$} & $\mathrm{T}-1$ & $4.82 \times 10^{5}$ & $3.01 \times 10^{5}$ & $13.63 \pm 9.10 \times 10^{5}$ & $3.09 \times 10^{3}$ & $8.07 \pm 6.61 \times 10^{3}$ \\
\hline & $\mathrm{T}-2$ & $23.5 \times 10^{5}$ & $14.1 \times 10^{5}$ & & $17.8 \times 10^{3}$ & \\
\hline & $\mathrm{T}-3$ & $10.9 \times 10^{5}$ & $5.90 \times 10^{5}$ & & $5.24 \times 10^{3}$ & \\
\hline & $\mathrm{T}-4$ & $27.5 \times 10^{5}$ & $19.3 \times 10^{5}$ & & $6.14 \times 10^{3}$ & \\
\hline \multirow[t]{4}{*}{ Summer } & $\mathrm{T}-1$ & $2.92 \times 10^{5}$ & $2.62 \times 10^{5}$ & $2.91 \pm 0.43 \times 10^{5}$ & $18.6 \times 10^{3}$ & $17.33 \pm 3.06 \times 10^{3}$ \\
\hline & $\mathrm{T}-2$ & $3.81 \times 10^{5}$ & $2.73 \times 10^{5}$ & & $13.7 \times 10^{3}$ & \\
\hline & $\mathrm{T}-3$ & $3.14 \times 10^{5}$ & $2.38 \times 10^{5}$ & & $16.2 \times 10^{3}$ & \\
\hline & $\mathrm{T}-4$ & $2.91 \times 10^{5}$ & $2.79 \times 10^{5}$ & & $20.8 \times 10^{3}$ & \\
\hline
\end{tabular}


Table 2. Biochemical tests for identification of the bacteria isolated from the river Turag.

\begin{tabular}{|c|c|c|c|c|c|c|c|c|c|}
\hline \multirow{2}{*}{$\begin{array}{l}\text { Isolate } \\
\text { No. }\end{array}$} & \multicolumn{8}{|c|}{ Biochemical profile } & \multirow[t]{2}{*}{ Identified bacteria } \\
\hline & V.P. & Methyl red & Motility & Citrate & Propionate & Starch & Tyrosine & Lecithinase & \\
\hline T1N1 & + & - & - & + & - & + & - & + & Bacillus acidocaldarius \\
\hline T3N1 & + & + & + & + & - & - & - & + & \\
\hline $\mathrm{T} 4 \mathrm{P} 4$ & - & + & + & + & + & - & + & - & \\
\hline T1N2 & + & - & - & + & - & + & - & + & B. coagulans \\
\hline $\mathrm{T} 1 \mathrm{~N} 4$ & - & - & + & + & - & + & - & + & B. globisporus \\
\hline T1P1 & - & + & + & + & - & + & - & - & B. lentus \\
\hline T4P3 & - & - & - & + & - & + & - & + & \\
\hline T1P2 & + & + & + & + & - & + & + & - & \\
\hline Т3Р1 & - & - & + & + & - & + & - & + & \\
\hline Т3P2 & + & + & + & + & - & - & - & + & B.pumilus \\
\hline $\mathrm{T} 2 \mathrm{~N} 1$ & + & - & + & + & - & - & - & + & B. stearothermophilus \\
\hline T1N3 & + & - & - & + & - & + & - & - & Brochothrix thermosphacta \\
\hline $\mathrm{T} 2 \mathrm{~N} 2$ & + & - & + & + & - & + & - & + & Caryophanon sp. \\
\hline T4N2 & + & - & + & + & - & + & + & + & \\
\hline T4N3 & + & + & + & + & - & + & - & + & \\
\hline T4N4 & + & + & - & + & - & - & - & + & Renibacterium salmoninarum \\
\hline T3N2 & + & + & + & - & - & + & + & + & Alcaligenes denitrificans \\
\hline T4N1 & + & + & + & - & - & + & + & + & \\
\hline Т3Р3 & - & - & + & - & - & + & + & + & \\
\hline T4M1 & + & + & + & + & + & + & + & + & Citrobacter freundii \\
\hline $\mathrm{T} 1 \mathrm{M} 3$ & - & + & + & - & + & + & - & + & Escherichia coli \\
\hline T4M2 & - & + & - & + & + & - & + & - & \\
\hline $\mathrm{T} 2 \mathrm{P} 1$ & + & - & + & - & - & + & - & + & Plesiomonas shigelloides \\
\hline T4P1 & + & - & + & - & - & + & - & + & \\
\hline $\mathrm{T} 4 \mathrm{P} 2$ & + & - & + & + & + & + & - & + & \\
\hline T1M2 & + & + & + & - & - & + & + & + & \\
\hline T2M2 & - & - & + & - & - & - & - & + & \\
\hline T3M1 & - & + & + & + & + & + & - & + & \\
\hline T2M1 & + & + & + & - & - & + & - & + & Proteus myxofaeciens \\
\hline T1M1 & - & - & + & + & + & - & - & + & Proteus rettgeri \\
\hline
\end{tabular}

$+=$ Positive, $-=$ Negative result. 
Table 3. Physicochemical properties of the water samples of the river Turag in different seasons.

\begin{tabular}{|c|c|c|c|c|c|c|c|c|c|c|c|}
\hline \multicolumn{12}{|c|}{ Rainy season } \\
\hline $\begin{array}{l}\text { Sampling } \\
\text { site }\end{array}$ & $\mathrm{pH}$ & $\begin{array}{l}\text { Temp. } \\
\left({ }^{\circ} \mathrm{C}\right)\end{array}$ & $\begin{array}{c}\mathrm{DO} \\
(\mathrm{mg} A)\end{array}$ & $\begin{array}{l}\text { BOD } \\
(\mathrm{mg} \Lambda)\end{array}$ & $\begin{array}{l}\text { COD } \\
(\mathrm{mg} /)\end{array}$ & $\begin{array}{l}\text { TDS } \\
(\mathrm{mg} A)\end{array}$ & $\begin{array}{l}\text { Conductivity } \\
(\mu \mathrm{s} / \mathrm{cm})\end{array}$ & $\begin{array}{c}\text { Turbidity } \\
\text { (NTU) }\end{array}$ & $\begin{array}{c}\text { Sulfate } \\
(\mathrm{mg} /)\end{array}$ & $\begin{array}{c}\text { Chloride } \\
(\mathrm{mg} /)\end{array}$ & $\begin{array}{c}\text { Fluoride } \\
(\mathrm{mg} \Lambda)\end{array}$ \\
\hline $\mathrm{T}-1$ & 7.10 & 27.0 & 0.63 & 54 & 62 & 75 & 150 & 22.70 & 51.20 & 33.10 & 0.75 \\
\hline $\mathrm{T}-3$ & 7.03 & 27.5 & 0.72 & 37 & 51 & 74 & 149 & 17.20 & 50.00 & 34.50 & 0.62 \\
\hline $\mathrm{T}-4$ & 7.08 & 28.0 & 0.69 & 31 & 57 & 82 & 164 & 17.90 & 48.20 & 34.70 & 1.03 \\
\hline Average $\pm S D$ & $\begin{array}{c}7.08 \pm \\
0.03\end{array}$ & $\begin{array}{c}27.5 \pm \\
0.41\end{array}$ & $\begin{array}{c}0.64 \pm \\
0.08\end{array}$ & $\begin{array}{c}37.75 \pm \\
11.35\end{array}$ & $\begin{array}{c}59.15 \pm \\
5.20\end{array}$ & $\begin{array}{c}77.75 \pm \\
3.86\end{array}$ & $\begin{array}{c}155.75 \pm \\
7.41\end{array}$ & $\begin{array}{c}22.03 \pm \\
6.03\end{array}$ & $\begin{array}{c}51.70 \pm \\
4.00\end{array}$ & $\begin{array}{c}35.08 \pm \\
2.08\end{array}$ & $\begin{array}{c}0.97 \pm \\
0.37\end{array}$ \\
\hline T-1 & 7.56 & 22.0 & 0.43 & 63 & 73 & 212 & 424 & 39.90 & 54.10 & 36.90 & 0.20 \\
\hline $\mathrm{T}-2$ & 7.53 & 23.0 & 0.69 & 32 & 55 & 211 & 423 & 41.90 & 55.00 & 36.50 & 0.26 \\
\hline $\mathrm{T}-3$ & 7.53 & 23.5 & 0.99 & 53 & 64 & 227 & 454 & 38.60 & 58.60 & 42.10 & 0.28 \\
\hline $\mathrm{T}-4$ & 7.52 & 24.0 & 0.97 & 46 & 65 & 245 & 489 & 35.20 & 61.90 & 46.00 & 0.26 \\
\hline Average \pm SD & $\begin{array}{c}7.54 \pm \\
0.02\end{array}$ & $\begin{array}{c}23.13 \pm \\
0.85\end{array}$ & $\begin{array}{c}0.77 \pm \\
0.26\end{array}$ & $\begin{array}{c}48.50 \pm \\
13.03\end{array}$ & $\begin{array}{c}64.03 \pm \\
5.74\end{array}$ & $\begin{array}{c}223.75 \pm \\
15.95\end{array}$ & $\begin{array}{c}447.5 \pm \\
31.18\end{array}$ & $\begin{array}{c}38.90 \pm \\
2.82 \\
\end{array}$ & $\begin{array}{c}57.40 \pm \\
3.57\end{array}$ & $\begin{array}{c}40.38 \pm \\
4.54\end{array}$ & $\begin{array}{c}0.25 \pm \\
0.03\end{array}$ \\
\hline \multicolumn{12}{|c|}{ Summer } \\
\hline $\mathrm{T}-2$ & 6.98 & 29.5 & 0.31 & 60 & 69 & 465 & 829 & 74.90 & 100.70 & 95.20 & 1.01 \\
\hline $\mathrm{T}-3$ & 6.99 & 29.5 & 0.38 & 34 & 40 & 434 & 868 & 86.20 & 102.40 & 93.50 & 0.51 \\
\hline $\mathrm{T}-4$ & 7.09 & 31.0 & 0.62 & 39 & 65 & 435 & 870 & 73.10 & 101.50 & 94.40 & 0.36 \\
\hline Average \pm SD & $\begin{array}{c}6.99 \pm \\
0.08\end{array}$ & $\begin{array}{c}30.00 \pm \\
0.71\end{array}$ & $\begin{array}{c}0.38 \pm \\
0.17\end{array}$ & $\begin{array}{c}49.50 \pm \\
15.29\end{array}$ & $\begin{array}{c}63.38 \pm \\
12.71\end{array}$ & $\begin{array}{c}441.75 \pm \\
15.52\end{array}$ & $\begin{array}{c}858.25 \pm \\
19.57\end{array}$ & $\begin{array}{c}79.53 \pm \\
6.49\end{array}$ & $\begin{array}{c}100.85 \pm \\
1.53\end{array}$ & $\begin{array}{c}93.4 \pm \\
2.05\end{array}$ & $\begin{array}{c}0.55 \pm \\
0.32\end{array}$ \\
\hline
\end{tabular}


effluents particularly sulphate, chloride and fluoride were 400, $150-600$ and $1 \mathrm{mg} \Lambda$, respectively. The result of the present study revealed that the contents of thus chemical were satisfactory from the pollution point of view as they were within the standard range (maximum level of sulphate $100.85 \pm 1.53 \mathrm{mg} \Lambda$, chloride $93.4 \pm 2.05 \mathrm{mg} /$ and fluoride 0.97 $\pm 0.37 \mathrm{mg} \Lambda)$.

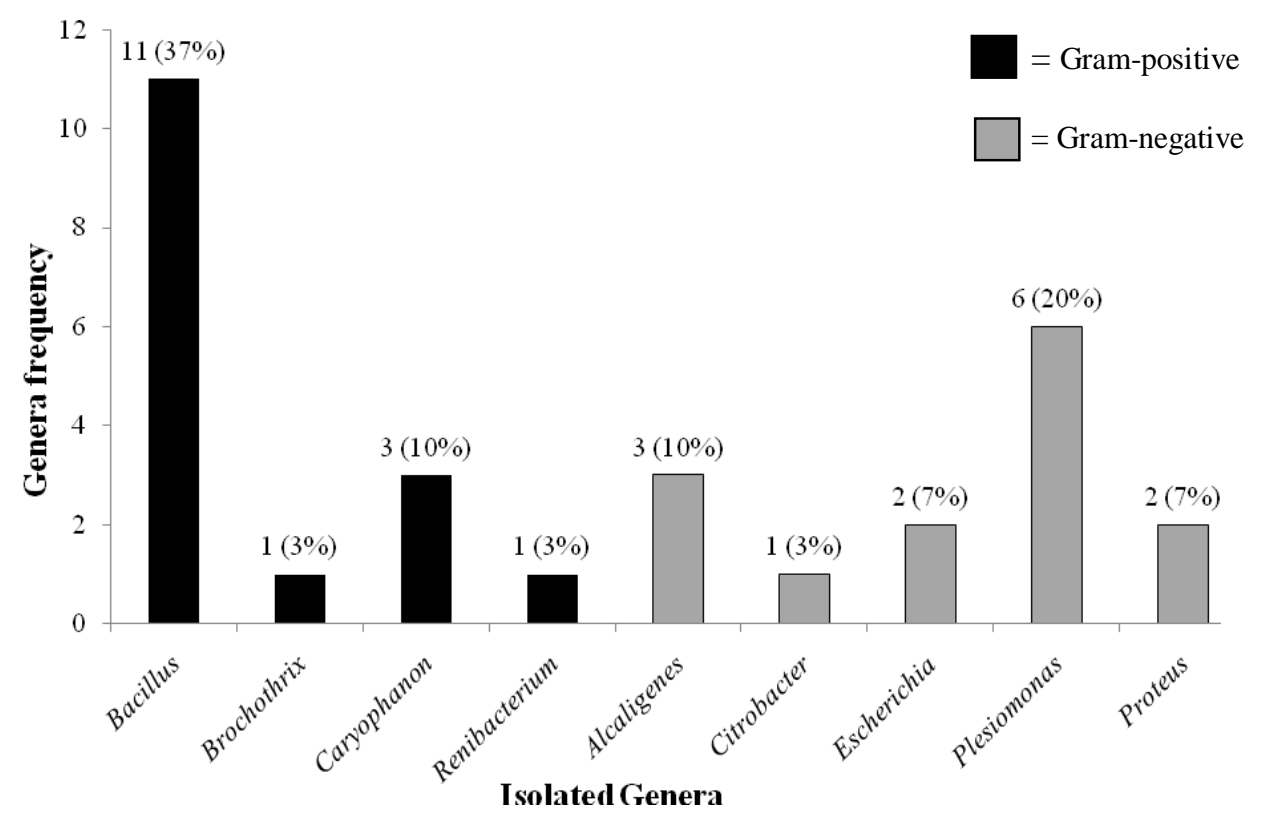

Fig. 2. Genera frequency of the identified bacterial isolates.

The load of aerobic heterotrophic bacteria and the presence and abundance of enteric and related bacteria such as Plesiomonas, Alcaligenes, Escherichia, Proteus etc. in the water clearly showed significant level of microbial pollution of the river. On the basis of DO, BOD and COD values, the river Turag water was found to be polluted. Fecal contamination via increasing anthropogenic activities in the catchment could be the main reason for it. Well managed waste disposal system should be practiced to save the river Turag from the pollution. Whereas more detailed study would be needed especially on the multi-drug resistance as well as on the hemolytic activities of the isolated Gramnegative bacteria. Research should be carried out in future which will have significant role towards the gastrointestinal disease manifestation for the people who are directly associated with this river.

\section{References}

1. Haigh MJ 2004. Sustainable management of headwater resources: The Nairobi 'Headwater' Declaration (2002) and Beyond. Asian J. Water, Environ. Pollut. 1(1-2): 17-28. 
2. Karn SK and H Harada 2001. Surface water pollution in three urban territories of Nepal, India and Bangladesh. Environ. Manage. 28(4): 438-496.

3. GOB-UNICEF 1991. Rural water supply and sanitation program. 1992-1999, Dhaka.

4. Alam AMS, ANME Haque, MY Ali, SA Tarafdar and AH Khan 1993. Heavy element contaminants in aquatic ecosystems. In: Hypertrophic and Polluted Freshwater Ecosystems: Ecological Bases for Water Resources Management (Tilzer MM and M Khondker eds). Proc. Int. Symp. Limnol. Botany Dept., Dhaka Univ. Bangladesh. pp. 91-96.

5. Hasan MK, MK Hasan and A Hossain 2013. A comparative study of water quality in the peripheral rivers of Dhaka city. Dhaka Univ. J. Biol. Sci. 22(2): 127-136.

6. Sikder MT, M Yasuda, Yustiawati, SM Syawal, T Saito, S Tanaka and M Kurasaki 2012. Comparative assessment of the water quality in the major rivers of Dhaka and West Java. Int. J. of Environment and Pollution 2(4): 8-13.

7. Geldreich EE 1996. Pathogenic agents in freshwater resources. Hydrological processes. 10: 315-333.

8. APHA 1998. Standard Methods for the Examination of Water and Wastewater, (20 ed.). American Public Health Association, Washington, D.C.

9. SAB (Society of American Bacteriologists) 1957. Manual of Microbiological Methods. McGraw-Hill Book Co. Inc. NY. pp. 315.

10. Eklund C and CE Lankford 1967. Laboratory Manual for General Microbiology. Prentice-Hall Inc. Englewood Cliffs. New Jersey. pp. 299.

11. Collins CH and PM Lyne 1984. Microbiological Methods (5 ${ }^{\text {th }}$ ed.). Butterworth and Co. (Publishers) Ltd. London. pp. 448.

12. Sneath PHA, NS Mair, ME Sharpe and JG Holt (eds)1986. Bergey's Manual of Systematic Bacteriology ( $9^{\text {th }}$ ed.). The Williams and Wilkins Co. Baltimore, USA 2: pp. 1599.

13. WHO 1987. Manual for laboratory investigations of acuteenteric infections. CDD/83.3 Rev. 1. pp. 113.

14. Krieg NR and JG Holt (eds.) 1984.Bergey's manual of systematic bacteriology. The Williams and Wilkins Co. Baltimore, USA. 1: pp. 964.

15. Jackson ML 1967. Soil Chemical Analysis, Prentice Hall, Inc. Englewood Cliffs, N. J. USA. pp. 227-261.

16. Hunt J 1981. Determination of Total Sulfur in Small Amount of Plant Material. Anal. 105: 83-85.

17. Garnier J, P Servais and G Billen 1991. Bacterioplankton in the Seine River: Impact of the Parisian urban effluents. Can. J. Microbiol. 38: 56-64.

18. Garnier J, Billen G and Servais P 1992. Physiological characteristics and ecological role of small and large sized bacteria in a polluted river (Seine River, France). Arch Hydrobiol Ergebn. Limnol. 37: 83-94.

19. Hasan MM, MK Ahmed, F Hafiz, AMI Hussain, S Parveen and SR Tinni 2006. Load of heterotrophic and nitrifying bacteria in the sewage lagoon and the river Buriganga. Bangladesh J. Microbiol. 23(2): 93-97.

20. Saha ML, MR Khan, M Ali and S Hoque 2009. Bacterial load and chemical pollution level of the river Buriganga, Dhaka, Bangladesh. Bangladesh J. Bot. 38(1): 87-91. 
21. Godfree AF, Kay D and Wyer MD 1997. Faecal streptococci as indicators of faecal contamination in water. J. Appl. Micribiol. Symp. Supplement. 83: 110-119.

22. Khondker M and SG Abed 2013. Seasonality of phytoplankton productivity of the river Turag of Dhaka in relation to its water quality. Bangladesh J. Bot. 42(2): 287-294.

23. Bangladesh Gazette, Excess Copy 1997. Government of the People's Republic of Bangladesh, Ministry of Environment and Forestry.

24. Huq SMI and Alam MD 2005. A Hand Book on Analyses of Soil, Plant and Water. BACERDU, University of Dhaka. pp. 246.

(Manuscript received on 24 June, 2016; revised on 5 September, 2016) 